ment to him than a key to the classification adopted; it would probably be an improvement if, in future volumes, the author would prefix to these names the terms "Family," "Sub-Family," "Group," \&c., so as to allow the systematic value of the names themselves to be more readily appreciated. The two plates accompanying the volume are intended to give an idea of those structural characters on which the classification used in the work is based, and they also give three figures of larvæ borrowed from Schiodte; it may be hoped that these latter extraordinary forms may incite some student to continue the work of investigating the earlier stages of beetles, so ably pursued by the talented Dane whose recent decease is still a matter of general regret amongst entomologists. The structural diagrams II. and III. on Plate $\mathrm{A}$ are, as given, far from being successful. They are described as representing the under-skeleton, but, actually, onehalf of each of the diagrams represents the upper surface, and the manner in which the two halves are connected will inevitably suggest to a beginner that the structures displayed are those that would be seen on removing the parts covering the upper surface.

Mr. Fowler, as we have already stated, has taken great pains to make himself acquainted with the modern authorities, and to render his work as interesting as the nature of the subject and its great extent will permit; his efforts in these directions will no doubt be duly appreciated, and his work will, it may be hoped, find a place in the libraries of ail our local museums, as well as on the bookshelves of the amateur.

D. S.

\section{BRITISH STALK-EYED CRUSTACEA AND SPIDERS}

British Stalk-eyed Crustacea and Spiders. By F. A. A. Skuse. (London: Swan Sonnenschein, Lowrey, and Co., 1886.$)$

THIS is a modest little volume of 126 pages, professedly written for the "tyro." We are in. formed, on p. 14, that the "pages do not profess to be either scientific or in the least anything beyond the production of a humble admirer of Nature, and only intended to put the reader on the road to the investigation of the creatures written about." This being so, it would be unfair to judge the work from the stand-point of more special treatises, and we need do no more than comment upon the introduction of a somewhat antiquated system of classification and of minor errors which would be unpardonable in a work of greater pretensions.

The book is a clearly stated compilation, and is, so far as it goes, fairly accurate and up to date. There is, manifestly, little room for originality, and the reader must be prepared to find that most of the more pleasing passages-those dealing with the habits of the animals described-are, of necessity, quotations from earlier authors, references to whose works are in all cases given as footnotes.

The subject-matter is apportioned into nine chapters and an introduction, and it deals with methods and accessories as fully as with the animals themselves. Under the head of Development (Chapter III.) are to be found the facts of morphology and physiology which fall within the scope of the work. It is in this that the author is at his worst, and there is much here which stands in need of revision. We are told, in the introduction, that "the earliest known insects have been found in the Devonian, so probably there also existed spiders." Taking the context into consideration, it is surprising that the author should thus presuppose the discovery of Palæozoic spiders, and overlook that of Silurian scorpions and cockroaches, the former so well to his purpose.

"Big-tails," "Queer-tails," and "Little-tails" are renderings of Macrura, Anomoura, and Brachyura as unfortunate as they are unconventional.

The illustrations are good as a whole; some are excellent, being faithful copies of standard figures. More spiders might be advantageously delineated, and exception must be taken to the wretchedly wooden drawings of crustacean larvæ, especially of the young lobsters (p. 27). For the latter the author would do well to substitute, should a second edition be demanded, the strikingly truthful drawings of Sars ("Om Hummerens postembryonale udvikling," Christiania, 1874), or, failing those, Kent's figures ("International Fisheries Exhibition Literature," vol. vi. "Conferences").

There is much truth in the author's assertion (p. 10) that "everybody knows a crab. Everybody knows a spider. But it is just these every-day things that people know really least about; while, on the contrary, things that must be sought for in order to be seen are often most commonly known." The writer is true to this tenet, and his book ought, in the hands of an intelligent "tyro," to be productive of good results; while passages such as that in which he describes (p. 73) the construction of the spider's web are well calculated to arouse that enthusiasm which he is sanguine enough to presuppose. The apprecintion of the beautiful in Nature must precede the devotion to that which is more useful, and the little handbook before us, invested, as it is throughout, with a true dignity of purpose, will serve as a means to this desired end.

\section{OUR BOOK SHELF}

Catalogue of the Fossil Mammalia in the British Museum, (Natural History) Cromwell Road, S.W. Part IV. Containing the Order Ungulata, Sub-order Proboscidea. By Richard Lydekker, B.A., F.G.S. (London: Printed by Order of the Trustees, I886.)

THE collection of Proboscidean remains preserved in the British Museum is by far the largest in any Museum in the world; containing as it does the splendid collections made in the Siwaliks of India by Sir Proby T. Cautley, the unrivalled British series of mammoth remains, the unique collection of pygmy-elephant remains from Malta, the series of remains of dinotherium and mastodon, from Eppelsheim, \&c., and a fine collection of American mastodons from the United States and from South America.

An immense collection like this, containing remains belonging to nearly all the described forms, was admirably adapted for the study of transition forms, and Mr. Lydekker has not been content in this Catalogue with giving merely a detailed enumeration of the contents of the cases, but has written a full account of the families, genera, and most of the species of the known extinct Proboscidea. In a short introduction he gives some most interesting notes on the geographical and geological distribution of the species. In reference to the subject of the structure of the cheek-teeth Mr. Lydekker thinks that this can be 